\title{
A Widening Parental Leisure Gap: The FAmily as a Site for Late Modern DiFFERENTIATION AND CONVERGENCE in LeISURE TIme Within CANadA, THE UNITED KINGDOM AND THE UNITED STATES $^{1}$
}

\author{
GLenN J. StalkeR
}

\begin{abstract}
This study assesses trends in leisure time by life course and family characteristics in Canada, the United Kingdom, and the United States. Using national time-use data collected since the mid-1960s, it is hypothesized that important family characteristics are responsible for substantial variation in leisure time that is not recognized in accounts of leisure time among working adults or within national populations. An important finding indicates that leisure is either stable or has increased somewhat in the three Western democracies studied. Social characteristics, family, and employment contexts account for considerable variation in leisure time. Findings demonstrate an increased disadvantage in leisure time among parents of young children after controlling for social background characteristics. Analyses demonstrate the need to qualify accounts of over-work and the double-burden on available leisure time. The perspective of structural constraints integrates neoclassical economic approaches to marginal utility maximization and sociological approaches to gender, and clarifies the impact of changed economic relations that produce less gendered though more differentiated patterns of leisure when parenting.
\end{abstract}

Keywords: life course, leisure, gender, time-use, comparative analysis, work, double burden, parenting, welfare regimes, dependent labour theory, differentiation, modernity

Résumé. Cette étude évalue les tendances du temps de loisirs selon les caractéristiques familiales et viagères au Canada, au Royaume-Uni et aux États-Unis. En utilisant les données de l'emploi du temps recueillies à l'échelle nationale depuis le milieu des années 1960 , on fait l'hypothèse que les caractéristiques familiales

1. Acknowledgements: The author would like to thank Michael Friendly for suggestions made. Appreciation and gratitude is given to the directors of the Multination Time Use Study for their continued efforts and for making these data available. 
importantes sont responsables de la variation substantielle de temps de loisirs qui n'est pas reconnue dans les comptes de temps de loisirs chez les adultes en emploi ou au sein des populations nationales. Une constatation importante indique que les loisirs sont stables ou ont légèrement augmenté dans les trois démocraties occidentales étudiées. Des caractéristiques sociales, des contextes familiaux et de l'emploi expliquent la variation considérable dans le temps de loisirs. Les constatations démontrent un désavantage accru dans le temps de loisirs parmi les parents de jeunes enfants par suite d'un contrôle des caractéristiques d'origine sociale. Des analyses démontrent la nécessité de qualifier les comptes de surmenage et le fardeau double sur le temps de loisirs disponible. Une théorie du travail sur les personnes à charge aide à comprendre l'impact des relations économiques modifiées qui produisent des tendances de loisirs axées moins sur le sexe mais plus différenciées à propos de l'éducation des enfants.

Mots clés: parcours de vie, loisirs, sexe, l'emploi du temps, analyse comparative, travail, double fardeau, l'éducation des enfants, régimes de protection socialie, une théorie du travail sur les personnes à charge, différenciation, la modernité

onsiderable social change has affected the gendered division of labour within the contemporary family. Women have entered the labour market in greater numbers in recent decades; higher educational achievement, postponed marriage, and delayed childrearing affect the demography of developed nations and contribute to change in gender roles (Cohen and Bianchi 1999; Schlesinger and Schlesinger 1989). The impact of work and family on leisure time has not been specifically addressed in general trends in leisure time among national populations. Furthermore, the large amount of attention directed to resolving the "overwork" debate focused on averages among national aggregates (Gershuny 2000; Robinson and Godbey 1997; Schor, 1992) and did not initially investigate growing variation in leisure by parental and employment status.

Considerable debate has attempted to determine if leisure has increased broadly within society, as expected by early proponents of the Leisure Society thesis (Dumazedier 1967), or alternatively, if Americans are increasingly Overworked (Schor 1992). Researchers using time-use data have argued that leisure time has increased in most Western nations (Gershuny 2000; Robinson and Godbey 1997; Stalker 2006). Using time diary collected data, they challenged perspectives that leisure had been sacrificed as Americans increasingly worked longer hours (Schor 1992; Cross 1993).

Schor's (1992) analysis used data from the American Current Population Survey (CPS) and measured employment time by asking respondents to indicate how many hours they worked in a typical week, thereby relying on the ability of respondents to recall their working hours. Data 
collected using time-use diaries is an alternative means to measure the amount of time that individuals participate in all daily activities in addition to their working hours. Robinson $(1999,1985)$ argued that this method reduced the bias that occurs when respondents are asked to recall the amount they worked in a typical week, and yielded more accurate accounts of the actual amount of time allocated to paid work and leisure. The time-use diary method of data collection is also sensitive enough to capture breaks during work time, such as taking lunch, errands, and coffee breaks that would otherwise be included in weekly work totals (Robinson and Gershuny 1994).

The general population trend toward greater leisure time in Western nations is difficult to reconcile with many national reports that the perception of being harried, or time-stressed, has increased (Jacobs and Gerson 2004; Jacobs and Jacobs 1998; Garhammer 2002; Robinson and Godbey 1997; Sullivan and Gershuny 2001). While leisure time may be increasing at the level of the general population, existing findings do not account for growing differences in available leisure time based on parental status and family roles.

Considerable variation in time use is accounted for by social characteristics that represent different stages in the life-course (Rapoport and Rapoport 1975). Parenting and the pursuit of paid employment demand investments in time and energy. Differentiation between social roles by the amount of available leisure time is a source of important social change that may contribute to increasingly dissimilar patterns of lived experience. Social differentiation is the recognition or constitution of social differences between groups or categories of people, that are invariably shaped by stratification, status, and social roles (Vosko 2003). Complex social change in the economy, the educational system, and the family has the potential to destabilize and disorganize social relations (Crook, Pakulski and Waters 1992), contributing to new inequalities or similarities between groups and social actors with different roles. For instance, differentiated, and somewhat disorganized, patterns of family relations provide the opportunity for new familial relationships to be recognized. Greater opportunities for same-sex couples to participate in parenting are available; liberalized divorce laws contribute to increased family dissolution, increased education delays conjugal life and the success that women have experienced in the labour market dramatically changes the material basis of the family and gender relations.

\section{Theses of Convergence in Leisure Time by Gender and}




\section{Differentiation by Life-COURSe ChaRaCteristics}

Gershuny (2000) used time-use data in his international comparative analysis of work and leisure and concluded that the amount of leisure time available to men and women had increasingly converged, while a considerable number of cross-sectional findings show that men still have more available leisure time (Bianchi 2003; Bittman 1998, 2000; Coverman and Sheley 1986; Firestone and Shelton 1994; Sayer 2005; Thrane 2000). While the availability of leisure has become more similar on the basis of gender, other sources of social change may contribute to increasingly differentiated amounts of time among individuals in different stages of the life-course. An individual's time-use can be considered a program that is comprised of different projects that include employment, parenting, and being a supportive spouse (Mårtensson 1979). The distribution of leisure in society among parents and nonparents has not been widely investigated as an emerging source of time inequality.

Participation in the labour market has important consequences for the organization of roles and activity within the family. Becker's (1981) economic theory of the family proposes that couples rationally decide how best to maximize gains to their marriage. The human capital that each individual brings to a partnership is tested in both market and domestic work contexts and arrangements that produce the maximum marginal utility within the family are adopted. This provides a successful family adaptation to conditions within the labour market and the home. Frequently, the impact of male economic opportunity is emphasized (White and Rogers 2000), since men have traditionally been more highly remunerated. This perspective shows that men's position within the labour market shapes the timing of marriage (Easterlin 1978) and that the contemporary delay in time to marriage has been attributed to young men's difficulty in finding breadwinning wage labour (Oppenheimer 1997).

Becker's theory leads to the assumption that men and women will have roughly equal amounts of leisure time since their roles are complementary. Men will specialize in the labour market so long as they can realize a competitive advantage, while women will specialize in domestic work so long as that work makes the largest contribution to the household. When the breadwinner model of the family was prevalent, family policies directly supported the gendered division of labour. The organization of men's work, supported through union collective bargaining, additionally entrenched men's work in the public sphere and limited women's opportunities in market work except in times of national military crisis (Ursel 1992). Family and work policies contributed to a division of labour that emphasized the gains men could realize in the 
labour market and the considerable contribution women made through the raising of children and care provided to the household. The erosion of the breadwinner model of the family has been attributed to declining male wages (Levy 1995). Becker's theory, however, adapts well to changes in economic organization. Declining male wages and greater female educational attainment increase the marginal utility of women's paid work and hence, predict greater female labour force participation and an evolving gendered division of labour. The rational organization of complementary gender roles suggests that, regardless of the ratio of market to domestic work, differences in leisure between men and women should be negligible.

Hochschild and Machung's (1989) thesis of the double burden, however, argues that gender roles change slowly and that economic realities imperfectly predict gender role productive activity and leisure. Market labour is activity that defines and contributes to the construction of masculinity in the lives of men; domestic work and its traditional association with "women's work" is a cultural residue from a period in gender relations when men held considerable economic power within the family (Brines 1994). While men have increased the amount of domestic work they do, women have substantially increased their time in the labour market (Hochschild and Machung 1989; Shelton 1992; Stalker 2006). The double burden, the result of gender roles and ideology that are slow to change, predicts that women who are employed may need to sacrifice their leisure time to manage work and family roles. The persistence of gender ideology is reflected in structural social policies that have yet to adapt to rapid change within the family (Moen and Sweet 2003; Ursel 1992).

Aside from gender, little research has investigated variation in leisure time by other social characteristics, such as parental and employment status. Parental status is expected to have a greater effect on contemporary men's leisure time than in earlier decades. Declining male wages, higher female educational attainment, and increased female labour force participation have empowered new cohorts of women with opportunities to provide for their households. Sayer (2005) has shown that parenting young children increases the amount of unpaid work that both mothers and fathers complete. Rising female wages and accumulated human capital are expected to contribute to greater bargaining power within the family. New economic realities of family life predict the greater involvement of men in all aspects of parenting and private household work. Attitudes are slow to change but are increasingly supportive of a greater role for men within the family (Brewster and Padavic 2000). 
There is a contemporary need to reexamine the double burden of female paid and unpaid work and its impact on leisure. Becker's perspective predicts that fathers will become increasingly invested in the domestic work of children given the gains that women can realize through market labour. The female double burden of market and domestic work and its impact on available leisure may be increasingly shared by working fathers. This will be the product of greater realized female economic gain and evolution in male gender roles that were at one time limited by the idealization of the breadwinning man.

Consequently, the amount of leisure available to contemporary parents is expected to be much more limited than it was for parents in previous generations. The reorganization of productive and reproductive relations leaves less time available for leisure, that period in time when the gains of employment are intensely consumed. Increasingly, the doubleburden of working mothers may be experienced by working fathers resulting in a growing differentiation in the availability of time between parents and nonparents. This results in higher market and domestic work times for parents, or, alternatively more investment in production and reproduction. This may contribute to reduced leisure time among parents, while individuals who do not have children have more leisure time available for consumption.

\section{Differentiation in Leisure Time from a Comparative Perspective}

The time available for leisure among workers and parents is expected to vary by the nation's welfare state regime. Welfare state regimes influence the policy resources that are available to workers and families when engaged in market and domestic work. National social welfare regimes (Esping-Anderson 1990) can be categorized along a continuum with liberal states, such as the US and Canada, choosing more market oriented solutions and social-democratic states, including Sweden and Norway, favoring universal state funded social policies. Differences exist within each category. While the US, Canada, and the UK may all be categorized as liberal, they nonetheless demonstrate many differences with respect to labour laws governing the hours of work, paternal leave policies, and entitlements to holiday time and unemployment assistance.

It is expected that average leisure times will be lower in more liberal welfare regimes given fewer protections and entitlements within the labour market. Esping-Anderson situates the US at the end of the liberal continuum, while Canada and UK both share some social democratic features that include more extensive labour protections, family allowances, and a universally funded public health care system. Becker's theory 
addresses the microeconomic realities of how family members negotiate their productive activity to best contribute to the strength of the household. Households respond to broader economic challenges that include the social policy contexts of their larger nations. Microeconomic theory recognizes that decisions within the family are made in response to a larger economic and political context that includes the relative power of women within the labour force and the social policies that support families. These larger social policy contexts shape the resources that are available to families and women within families, thereby potentially informing the micro economic negotiations of family life.

Four possible sources of variation in the effect of social characteristics by survey year will be investigated. First, Gershuny (2000) claims that gender roles have undergone a period of renegotiation since women began entering the labour market in greater numbers. The time allocated to paid and domestic work is becoming less gendered, as is leisure, and this convergence in male and female productive activity has reshaped the family as an institution that is not singularly dependent on one breadwinner. Using American Multinational Time Use Study (MTUS) data, the findings of Sayer (2005) contradict the expectation that the gap in male and female leisure time is converging in the United States on the basis of gender and suggest, rather, that inequality in leisure time among men and women increased between 1975-1998. This increase is attributed to the increased demands that women experience negotiating their roles in market labour and within the family. Given earlier reported trends, it is expected that leisure will have converged on the basis of gender in Canada and the United Kingdom, while the gendered leisure gap may have increased within the United States.

Second, the work of Hochschild and Machung (1989) and, in particular, Moen and Sweet (2003) provides a strong basis for the expectation of decreased leisure time among parents, especially among parents of young children. It is further expected that leisure time will have increased for individuals who do not have children resulting in a growing differentiation in leisure by parental status. According to Moen and Sweet, the contemporary difficulties experienced by parents with children result from social policy that has not caught up to the challenges faced by working parents. These changes have been fueled by far greater female labour force participation and the prevailing organization of work, in addition to existing policy arrangements, that may be contributing to increasingly constrained available leisure among working mothers.

Third, the gendered division of domestic and market work has become increasingly egalitarian (Gershuny 2000; Sayer 2005; Stalker 2006) suggesting that the greatest gains to marriage are no longer 
achieved through specialized gender roles. Women have increasingly been able to realize greater rewards in the labour market, while men are contributing more to domestic work. Dependent labour theory (Becker 1981) suggests that specialized market and domestic gender roles produce gains in household efficiency and that more equal divisions lose that specific advantage. Consequently, it is expected that being in a partnered relationship may increasingly hinder one's available leisure time as gender roles evolve from specialized production toward shared household responsibility in market and domestic work.

Finally, the relationship between one's market work and leisure time is expected to have changed over the periods studied in each country. Neoliberal labour market policies have deregulated labour markets making them more adaptable to international competition, but eroded many protections that stipulate the timing and length of when work is done (Bittman 1998; Esping-Andersen 1999). Resolution of the "overwork" debate that occurred between Schor (1992) and critics including Gershuny (2000) and Robinson and Godbey (1997) suggest that while working hours have remained relatively stable in most countries, employees working full-time have increased their working hours. Gershuny (2005) elaborated earlier findings and demonstrated that leisure time had become more polarized by socioeconomic status with higher skilled professional workers putting in more hours on the job. According to Gershuny, this represents a reversal of the leisure-status gradient found in Veblen's (1899) classical account of leisure and conspicuous consumption whereby busyness, not noble idleness, demonstrates social status. Given the possibility of increased work hours among those employed full-time and shifting values with respect to social status and leisure, it is expected that leisure time will increasingly vary by employment status over the periods of time studied in the United States, Canada, and the United Kingdom and that this is an important source of contemporary social change.

Folbre (1994) proposes an integrated perspective that more fully accounts for the rational actor's decision-making processes within complex and gendered structures of social constraint. Outcomes can reasonably be attributed to the constraints of one's gender and one's ability to realize gains in the labour market. Folbre argues that Becker's theory of time allocation and specialization in nonmarket domestic work overstates the role of individual decision making and exaggerates the efficiency of the outcome. Time allocation, as acknowledged by (Mårtensson 1979), cannot be solved individually given the interdependence of household members. Domestic work has additional value that may include the pleasure of caring for others that cannot be reduced to its replacement cost in the 
market. Consequently, the outcome that achieves the greatest marginal utility relative to the labour market may not adequately account for noneconomic factors that individuals value.

Folbre's framework to understand time allocation contextualizes individuals within groups and structures of constraint as shaped by social policy, the economy, the norms of one's gender, and one's assets and means. For instance, Ursel's (1992) extensive analysis of Canadian labour market and family policies indicates a reluctance among policy makers to socialize the costs of reproduction, despite the reduced prevalence of the "breadwinning" model of male market work, thereby constraining women's participation in labour markets. However, given linkages between structures and actors, in addition to integrating neoclassical economic insights, the structural constraint perspective more thoroughly accounts for social change in the allocation of time-use and the limitations experienced by social actors.

\section{Research Questions}

The main research questions to be addressed are:

1. Is the amount of time allocated to leisure time becoming more differentiated by employment and parental status?

2. Given similar liberal welfare state regimes in Canada, the United States, and the United Kingdom are similar trends and patterns of differentiation evident?

3. Is time for leisure converging on the basis of gender?

4. To what extent is change in leisure the result of compositional changes in the demographic characteristics of populations in different survey periods?

\section{DATA}

Data from the Multinational Time Use Study (MTUS, file 5.5.2), a harmonized dataset of randomly collected time-use surveys (Fisher et al. 2006) is utilized in this analysis. Beginning in the early 1960s, many nations began time-use data collection programs in an effort to provide both market and nonmarket accounts of national productive activity. While the MTUS includes data from 29 nations, only data from Canada, the United States, and the United Kingdom are selected since these nations had the most comparable measures over multiple survey years that represent change from the 1960s onward. The selection of these nations provides a meaningful basis on which to compare change in leisure time. 
All share a common economic system and, with respect to Canada and the UK, a shared parliamentary political system. Furthermore, all three have been classed as liberal welfare state regimes (Esping-Anderson 1990; Olsen 2002) and while the US is considered to be very market oriented in the provision of social welfare, both Canada and the UK provide roughly similar levels of social welfare benefit.

The Canadian surveys were conducted in 1971, 1981, 1986, 1992, and 1999; the American surveys in 1965, 1975, 1985, 1992, 1998, and 2003² the British surveys were administered in 1974, 1983, 1987, 1995, and $2000 .^{3}$ Only diaries that sum to 24 hours and not missing more than 60 minutes of uncoded time have been included in the MTUS. Details of each national survey, including full sample sizes and response rates, can be found in Appendix 1. Time-use diaries may be collected for one or more days. Diaries from Canada and the US collected time-use data for one diary day. Data collection in the UK included a week's worth of diary measurements for surveys administered in 1964, 1983, and 1987 while the 2000 survey collected data for two diary days. Diaries from these surveys were aggregated to produce a daily average per respondent.

All analyses are weighted using MTUS recommended sample weights. The MTUS uses each nation's originally proposed sample weight to account for the sampling design and specific oversampling of subgroups that may have occurred. The recommended weights adjust the original sample weight for potential oversampling of particular days within the week, thereby maintaining comparability between nations. Table 1 presents descriptive statistics and analysis sample sizes that account for missing data for each country by year of survey.

\section{The Dependent Variable}

Leisure time measured in minutes per day is the dependent variable in analyses. Total leisure time includes many specific leisure activities, but excludes time required for all market and domestic labour, personal hygiene, and night sleep. This objective definition of leisure time, emphasized by the time-use approach, is widely employed when studying leisure time (Ås 1982) because it excludes obligatory time, such as market labour and domestic work, that constrains an individual's leisure time.

\section{Independent and Control Variables}

2. A 1992 survey from the United States is excluded from analysis since it did not collect data on the conjugal status of respondents.

3. A 1961 survey from the United Kingdom is not included in the analysis because it lacked comparable variable information for conjugal status, education, and age. 


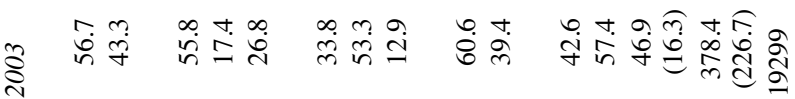

$\infty \quad \infty \%$ m.

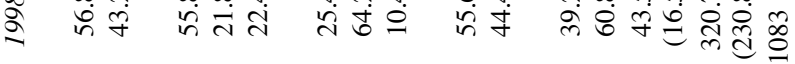

ऽ

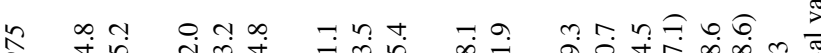

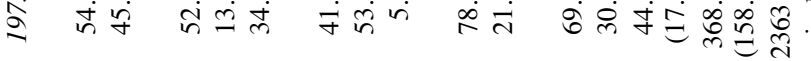

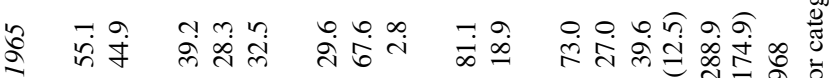

ஓ

全

ฟ

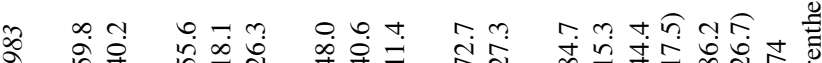

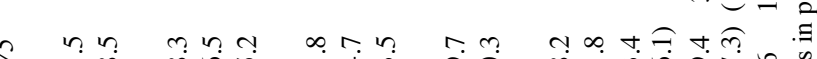

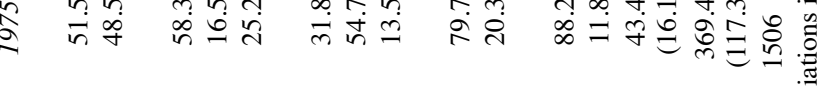

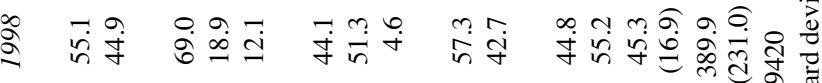

ล̆

焉

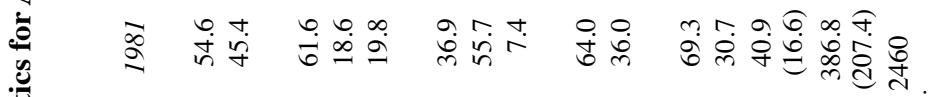

ล

ลิ

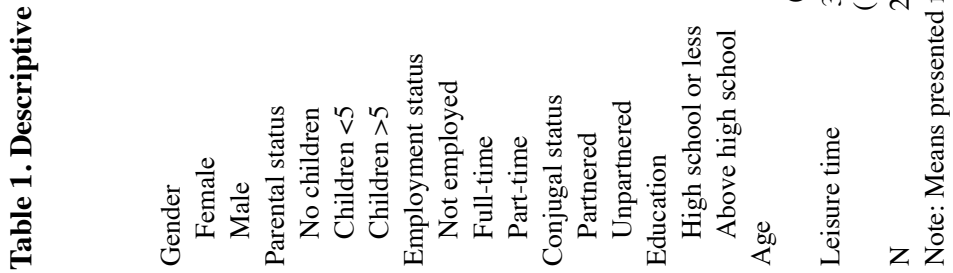


For each nation, the year in which the survey was conducted will be specified in statistical models as a categorical predictor using indicator regressors. The first time-use survey in each nation will be used as the comparison category to provide a reference point when evaluating change over time. Year of survey provides the marginal model from which elaboration of conditional relationships with social characteristics will be predicted.

The variable parental status has three categories: (1) children above the age of five; (2) children five years of age and younger; and (3) a reference category for no children. Employment status distinguishes between full and part-time employment specifying those not in the labour market as the reference category. Gender specifies the category for male as the reference category. Conjugal status has a category for those living in a marital or common-law partnership included in analyses; the reference category is those without partners.

Analyses were controlled for the education and age of the respondent. Education is categorized into an indicator variable with those who have attained greater than high school education included in model terms; the reference category represents those whose highest level of education is high school or less. The variable age is specified as a continuous covariate. ${ }^{4}$ Age-squared is specified in models since it is expected that leisure time will be highest at younger and older ages.

\section{Analytic Strategy}

Linear models using an analysis of covariance design are used to examine the effect of social and role characteristics on leisure time. Fitted values for marginal and conditional relationships are graphically presented (see Fox 1987). ${ }^{5}$ The structure of the model matrix $(\chi)$ is mirrored and proportional values for categorical predictors and median values for numeric predictors are held constant allowing fitted values to vary. The fitted values $\hat{n}_{0}=x_{0}^{\prime} b$ then express the effect on leisure time holding other predictors and controls constant. When calculating fitted values for a conditional relationship, the principle of marginality is respected and all lower order terms are included in the model.

4. The previous release of the MTUS (World 5.0) truncated the range of age to a maximum of 65 for specific national survey years.

5. R-language and environment for statistical computing (R Core Development Team, 2007), using the effects package for linear and generalized linear model prediction (Fox 2007). 


\section{RESULTS}

\section{Bivariate Relationships}

Table 1 demonstrates that recent average weekly leisure time is higher than in the mid 1960s and early 1970s, when data were first collected. The average amount of leisure time in each nation is remarkably similar, though the US has somewhat less leisure time while the UK has somewhat more leisure time by the last year for which data were collected (Canada, 390 minutes; UK, 394 minutes; US, 378 minutes).

Average age is roughly similar in all three nations and has increased over the years studied in Canada, from 37 in 1971 to 45 in 1998; in the UK, from 43 in 1975 to 46 in 2000; and in the US, from 40 in 1965 to 47 by 2003. Known differences between the nations are confirmed and include relative higher levels of education in Canada and the US, a higher proportion of partnered conjugal unions in the UK, and a larger proportion of individuals in the American labour force. Of greater interest is the increased proportion of households that do not have children. This trend is most evident in Canada and the US, less so in the UK. The proportion of Canadian and American households with young children under the age of five has substantially decreased.

\section{Model One: The Marginal Relationship between Leisure Activity and Time}

Model 1 regresses leisure activity in minutes against year. Change in fitted values of leisure time by year derived from Model 1 is presented in Figure 1. Results show that leisure time is, overall, highest in the UK and lowest in the US. At the population level, only small changes in daily leisure activity are evident in Canada and the UK. Leisure time increased slightly in the UK after 1987, while in Canada leisure time increased from 1971, the first year for which there is data, then remained constant throughout the 1980s and late 1990s. American leisure time has been more variable increasing throughout 1965-1985 decreasing considerably by 1998 only to rebound slightly by 2003 .

\section{Model Two: Leisure Activity over Time and Demographic Effects}

Model 2 accounts for variation in leisure over time that can be explained when accounting for demographic change within the population. Coefficients for each country are found in Table 2 (F-tests for terms specified in models can be found in Appendix 2). Controlling for demographic variables does not dramatically change the marginal relationship between year and leisure time found in Model 1 (Figure 1) indicating that 
38 C Canadian Journal of Sociology/Cahiers canadiens de sociologie 36(1) 2011

Figure 1. Fitted Number of Minutes of Leisure Activity for each Country, Derived from Model 1 and Model 2.

Canada

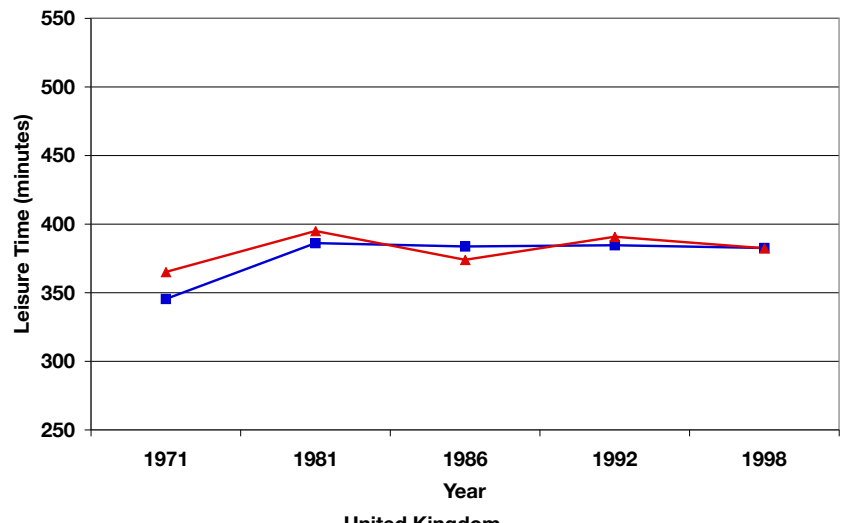

United Kingdom
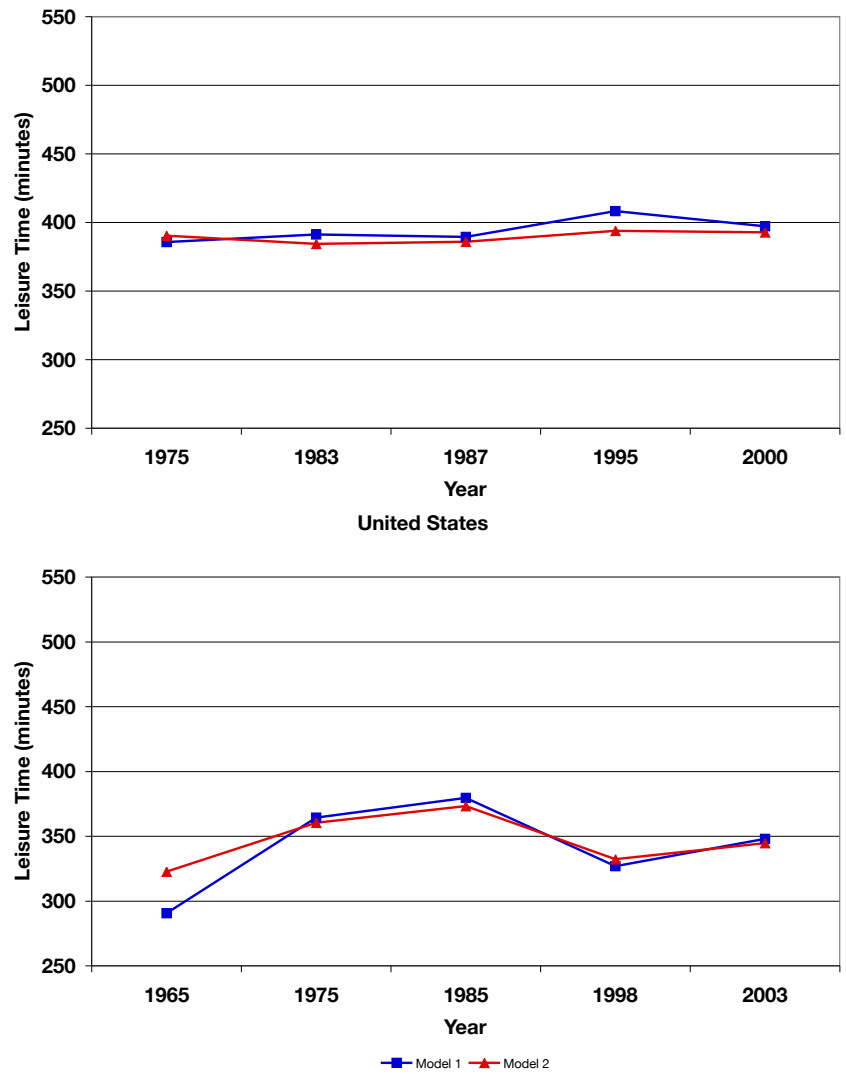
Table 2. Model Two Predicting Leisure Time by Demographic Predictors.

\begin{tabular}{|c|c|c|c|c|}
\hline Intercept & & $\begin{array}{c}\text { Canada } \\
589.2^{* * *} \\
(9.5)\end{array}$ & $\begin{array}{l}U K \\
586.1 * * * \\
(10.1)\end{array}$ & $\begin{array}{c}U S \\
582.1 * * * \\
(9.9)\end{array}$ \\
\hline \multirow[t]{4}{*}{ Year (Cnd/UK/US) } & $1981 / 83 / 75$ & $\begin{array}{l}29.8 * * * \\
(5.8)\end{array}$ & $\begin{array}{l}-5.7 \\
(5.5)\end{array}$ & $\begin{array}{l}37.8^{* * * *} \\
(5.8)\end{array}$ \\
\hline & $1986 / 87 / 85$ & $\begin{array}{c}8.9 \\
(4.8)\end{array}$ & $\begin{array}{l}-4.3 \\
(6.5)\end{array}$ & $\begin{array}{l}50.5^{* * * *} \\
(5.4)\end{array}$ \\
\hline & 1992/95/98 & $\begin{array}{l}25.5^{* * * *} \\
(4.8)\end{array}$ & $\begin{array}{c}3.5 \\
(4.0)\end{array}$ & $\begin{array}{c}9.8 \\
(4.6)\end{array}$ \\
\hline & $1998 / 2000 / 03$ & $\begin{array}{l}17.2 * * * \\
(4.8)\end{array}$ & $\begin{array}{c}2.4 \\
(4.0)\end{array}$ & $\begin{array}{l}22.0 * * * \\
(4.6)\end{array}$ \\
\hline \multirow[t]{2}{*}{ Children } & Children aged $<5$ & $\begin{array}{l}-82.6 * * * \\
(3.7)\end{array}$ & $\begin{array}{c}-82.7 * * * \\
(4.2)\end{array}$ & $\begin{array}{c}-68.6^{* * * *} \\
(3.7)\end{array}$ \\
\hline & Children aged $>5$ & $\begin{array}{c}-40.8 * * * \\
(3.2)\end{array}$ & $\begin{array}{c}-40.1 * * * \\
(3.3)\end{array}$ & $\begin{array}{c}-30.0 \\
(3.0)\end{array}$ \\
\hline Gender & Female & $\begin{array}{l}-69.4 * * * \\
(2.4)\end{array}$ & $\begin{array}{c}-66.0 * * * \\
(2.7)\end{array}$ & $\begin{array}{c}-52.3 * * * \\
(2.4)\end{array}$ \\
\hline \multirow[t]{2}{*}{ Employment status } & Full-time & $\begin{array}{c}-160.8^{* * * *} \\
(2.8)\end{array}$ & $\begin{array}{c}-134.1^{* * *} \\
(3.4)\end{array}$ & $\begin{array}{c}-157.6^{* * * *} \\
(3.0)\end{array}$ \\
\hline & Part-time & $\begin{array}{c}-89.9^{* * *} \\
(4.9)\end{array}$ & $\begin{array}{c}-81.8--- \\
(4.2)\end{array}$ & $\begin{array}{c}-94.8 * * * \\
(4.2)\end{array}$ \\
\hline Conjugal status & Partnered & $\begin{array}{c}-43.1 * * * \\
(2.8)\end{array}$ & $\begin{array}{c}-39.6 * * * \\
(3.0)\end{array}$ & $\begin{array}{c}-29.7 * * * \\
(2.7)\end{array}$ \\
\hline Education & $>$ high school & $\begin{array}{l}1.5 \\
(2.4)\end{array}$ & $\begin{array}{l}16.3 * * * \\
(3.1)\end{array}$ & $\begin{array}{l}1.2 \\
(2.4)\end{array}$ \\
\hline Age & & $\begin{array}{l}-3.4 * * * \\
(0.4)\end{array}$ & $\begin{array}{l}-1.8^{* * * *} \\
(0.4)\end{array}$ & $\begin{array}{c}-5.2 * * * \\
(.04)\end{array}$ \\
\hline $\mathrm{Age}^{2}$ & & $\begin{array}{l}0.04 * * * \\
(.004)\end{array}$ & $\begin{array}{l}0.01 * * * \\
(.004)\end{array}$ & $\begin{array}{l}0.06 * * \\
(.004)\end{array}$ \\
\hline $\mathrm{R}^{2}$ & & 0.22 & 0.23 & 0.20 \\
\hline $\mathrm{N}$ & & 29849 & 13405 & 28083 \\
\hline
\end{tabular}

variation in demographic characteristics within the population is not a strong factor accounting for trends in national leisure. Findings indicate a significant increase in leisure time in Canada, no significant change in the UK, and variable change increasing between 1965-1985 in the US, falling by 1998 and increasing slightly by 2003 . While this represents a net gain in American leisure time over 1965 values, the contemporary decrease in leisure that occurs after 1985 is substantial.

Coefficients from Model 2 confirm a number of expectations regarding the effect of demographic characteristics on leisure time. As predicted, leisure time is lower among women in each country. The effect of being in a partnered relationship also diminishes leisure time even after accounting for gender and children within the home. Predictably, full-time employment is the largest constraint on leisure time, while part- 
time employment affords greater time for leisure. Full-time employment is a larger constraint on the leisure time of Americans and Canadians than within the UK. The relationship between age and leisure is curvilinear with leisure time highest in younger periods of the life span and at older ages when the major life projects of parenthood and work no longer demand as much market and domestic work time. Aside from participation in market labour, having young children under the age of five is the second largest factor leading to decreased leisure time. Higher education has no effect on leisure time in the US and Canada, while it predicts moderate gains in leisure in the UK suggesting that human and cultural capital may be more important to leisure time in the UK.

\section{Model Three: Leisure Activity and Conditional Relationships between Gender, Employment Status, and Parental Status}

Model Three (coefficients are presented in Table 3, while F-tests for the overall significance of terms specified in models can be found in Appendix 3) extends the findings for leisure time by demographic predictors and controls by showing significant conditional relationships between gender, parental status, and employment status in all three countries. The three-way conditional effect between all three predictors is confirmed in Canada and the UK (Table 4).

In the US, a two-way conditional relationship between gender and parental status indicates that while men have more leisure time regardless of parental status, the effect of having children, especially under the age of five, increases the disparity between men and women's leisure time. Consequently, average leisure time is less gendered when children are not present in the home. Overall, men have greater leisure time regardless of their employment status. The significant conditional relationship between gender and employment status indicates that the gendered disparity in leisure time diminishes when men and women are employed full-time, while the gap in leisure is greatest when men and women are either employed part-time or not in the labour force. Finally, the conditional relationship between employment and parental status indicates that the lowest level of leisure time for each employment status occurs with young children under the age of five in the home. Having children under the age of five minimizes the difference in leisure time by employment status, while not being in the labour force exacerbates the difference between those not in the labour force with high levels of leisure and those employed full-time who enjoy far less leisure time. Findings for the US suggest that the gendered disparity in leisure time is shaped by parental 
Table 3. Model Three Predicting Leisure Time by Demographic Predictors and Interactions.

\begin{tabular}{|c|c|c|c|c|}
\hline \multirow{2}{*}{\multicolumn{2}{|c|}{ Intercept }} & Canada & $U K$ & $U S$ \\
\hline & & $\begin{array}{l}599.7 * * * \\
(9.7)\end{array}$ & $\begin{array}{l}595.2 * * * \\
(10.5)\end{array}$ & $\begin{array}{l}607.7 * * * \\
(10.4)\end{array}$ \\
\hline \multirow[t]{4}{*}{ Year (Cnd/UK/US) } & $1981 / 83 / 75$ & $\begin{array}{l}28.5^{* * * *} \\
(5.8)\end{array}$ & $\begin{array}{l}-8.0 \\
(5.4)\end{array}$ & $\begin{array}{l}35.3 * * * \\
(5.8)\end{array}$ \\
\hline & $1986 / 87 / 85$ & $\begin{array}{c}6.3 \\
(4.9)\end{array}$ & $\begin{array}{l}-6.2 \\
(6.5)\end{array}$ & $\begin{array}{l}46.3 * * * \\
(5.4)\end{array}$ \\
\hline & $1992 / 95 / 98$ & $\begin{array}{l}22.8 * * * \\
(4.8)\end{array}$ & $\begin{array}{c}1.9 \\
(5.0)\end{array}$ & $\begin{array}{l}63.8 \\
(7.1)\end{array}$ \\
\hline & $1998 / 2000 / 03$ & $\begin{array}{l}14.7 \text { *** } \\
(4.8)\end{array}$ & $\begin{array}{l}-0.3 \\
(4.0)\end{array}$ & $\begin{array}{l}18.7 * * * \\
(4.6)\end{array}$ \\
\hline \multirow[t]{2}{*}{ Parental status } & Children aged $<5$ & $\begin{array}{l}-81.6^{* * * *} \\
(11.8)\end{array}$ & $\begin{array}{l}-51.5^{* * *} \\
(15.5)\end{array}$ & $\begin{array}{c}-105.8^{* * * *} \\
(16.6)\end{array}$ \\
\hline & Children aged $>5$ & $\begin{array}{l}-51.8^{* * * *} \\
(11.1)\end{array}$ & $\begin{array}{c}-5.9 \\
(10.4)\end{array}$ & $\begin{array}{l}-49.8 * * * \\
(10.9)\end{array}$ \\
\hline Gender & Female & $\begin{array}{l}-73.3^{* * * *} \\
(5.1)\end{array}$ & $\begin{array}{l}-58.1 * * * \\
(5.7)\end{array}$ & $\begin{array}{c}-67.1 * * * \\
(5.7)\end{array}$ \\
\hline \multirow[t]{2}{*}{ Employment status } & Full-time & $\begin{array}{c}-199.9^{* * * *} \\
(4.5)\end{array}$ & $\begin{array}{c}-165.4 * * * \\
(5.2)\end{array}$ & $\begin{array}{l}-204.5^{* * * *} \\
(5.2)\end{array}$ \\
\hline & Part-time & $\begin{array}{l}-95.4 * * * \\
(10.6)\end{array}$ & $\begin{array}{l}-73.7 * * * \\
(10.4)\end{array}$ & $\begin{array}{l}-124.1 * * * \\
(8.3)\end{array}$ \\
\hline Conjugal status & Partnered & $\begin{array}{c}-39.8 * * * \\
(4.1)\end{array}$ & $\begin{array}{c}-30.0^{* * * *} \\
(4.6)\end{array}$ & $\begin{array}{c}-24.3 * * * \\
(4.0)\end{array}$ \\
\hline Education & $>$ high school & $\begin{array}{c}0.08 \\
(2.4)\end{array}$ & $\begin{array}{l}14.9 * * * \\
(3.1)\end{array}$ & $\begin{array}{l}-0.7 \\
(2.4)\end{array}$ \\
\hline Age & & $\begin{array}{l}-2.8 * * * \\
(0.4)\end{array}$ & $\begin{array}{l}-1.5 * * * \\
(0.4)\end{array}$ & $\begin{array}{l}-4.7 * * * \\
(0.4)\end{array}$ \\
\hline $\mathrm{Age}^{2}$ & & $\begin{array}{l}0.03 * * * \\
(.005)\end{array}$ & $\begin{array}{c}0.01 * * \\
(.004)\end{array}$ & $\begin{array}{l}0.05^{* * *} \\
(.004)\end{array}$ \\
\hline \multirow[t]{2}{*}{ Gender:Children } & $<5$ :Female & $\begin{array}{l}-53.6^{* * *} \\
(13.0)\end{array}$ & $\begin{array}{l}-72.8 * * * \\
(16.7)\end{array}$ & $\begin{array}{l}-16.0 \\
(17.7)\end{array}$ \\
\hline & $>5$ :Female & $\begin{array}{l}-20.2 * * * \\
(12.4)\end{array}$ & $\begin{array}{l}-85.6^{* * * *} \\
(12.5)\end{array}$ & $\begin{array}{c}-7.8 \\
(12.4)\end{array}$ \\
\hline \multirow[t]{2}{*}{ Gender:Emp.Status } & Female:Full-time & $\begin{array}{l}34.7 * * * \\
(5.9)\end{array}$ & $\begin{array}{l}30.5^{* * * *} \\
(6.8)\end{array}$ & $\begin{array}{l}41.7 * * * \\
(6.5)\end{array}$ \\
\hline & Female:Part-time & $\begin{array}{c}-2.0 \\
(13.0)\end{array}$ & $\begin{array}{l}-12.8 * * * \\
(12.1)\end{array}$ & $\begin{array}{l}29.4 * * \\
(10.8)\end{array}$ \\
\hline Gender:Cong.Status & Female:Partnered & $\begin{array}{l}-5.8 \\
(5.2)\end{array}$ & $\begin{array}{l}-15.8 * * \\
(5.7)\end{array}$ & $\begin{array}{l}-9.5 \\
(5.1)\end{array}$ \\
\hline \multirow[t]{4}{*}{ Children:Emp.Status } & $<5$ :Full-time & $\begin{array}{l}34.0^{* * *} \\
(12.8)\end{array}$ & $\begin{array}{c}-3.6 \\
(16.4)\end{array}$ & $\begin{array}{l}6.8 * * * \\
(17.3)\end{array}$ \\
\hline & $>5$ :Full-time & $\begin{array}{l}34.1 * * \\
(12.0)\end{array}$ & $\begin{array}{l}-18.2 \\
(11.6)\end{array}$ & $\begin{array}{l}3.4^{* *} \\
(11.8)\end{array}$ \\
\hline & $<5$ :Part-time & $\begin{array}{l}-37.2 \\
(33.0)\end{array}$ & $\begin{array}{l}-83.4^{*} \\
(35.9)\end{array}$ & $\begin{array}{r}5.6^{*} \\
(28.1)\end{array}$ \\
\hline & $>5$ :Part-time & $\begin{array}{l}-18.2 \\
(25.3)\end{array}$ & $\begin{array}{l}-34.1 \\
(25.4)\end{array}$ & $\begin{array}{c}-1.1 \\
(18.3)\end{array}$ \\
\hline \multirow[t]{4}{*}{$\begin{array}{l}\text { Gender:Children: } \\
\text { Emp. Status }\end{array}$} & $<5$ :Female:Full-time & $\begin{array}{l}39.4^{*} \\
(16.2)\end{array}$ & $\begin{array}{r}51.6^{*} \\
(21.7)\end{array}$ & $\begin{array}{l}-12.3 \\
(19.8)\end{array}$ \\
\hline & $>5$ :Female:Full-time & $\begin{array}{c}0.2 \\
(14.5)\end{array}$ & $\begin{array}{l}84.2 * * * \\
(15.5)\end{array}$ & $\begin{array}{c}0.5 \\
(14.4)\end{array}$ \\
\hline & $<5$ :Female:Part-time & $\begin{array}{r}84.7 * \\
(36.5)\end{array}$ & $\begin{array}{l}111.1 * * \\
(37.9)\end{array}$ & $\begin{array}{l}-13.4 \\
(30.9)\end{array}$ \\
\hline & $>5:$ Female:Part-time & $\begin{array}{c}-9.1 \\
(28.6)\end{array}$ & $\begin{array}{l}71.5^{* *} \\
(27.5)\end{array}$ & $\begin{array}{c}26.4 \\
(21.6)\end{array}$ \\
\hline \multicolumn{2}{|l|}{$\mathrm{R}^{2}$} & 0.22 & 0.24 & 0.21 \\
\hline \multicolumn{2}{|l|}{$\mathrm{N}$} & 29849 & 13405 & 28083 \\
\hline
\end{tabular}


Table 4. Three-Way Interaction between Gender, Employment Status, and Parental Status

\begin{tabular}{lcccccc} 
& \multicolumn{2}{c}{ Canada } & \multicolumn{2}{c}{ UK } & \multicolumn{2}{c}{ US } \\
& Men & Women & Men & Women & Men & Women \\
Employed full-time & & & & & & \\
$\quad$ Children <5 & 297.9 & 241.6 & 314.3 & 254.6 & 280.5 & 220.8 \\
$\quad$ Children >5 & 327.9 & 265.8 & 345.3 & 305.3 & 301.9 & 263.4 \\
$\quad$ No children & 345.5 & 303.4 & 369.3 & 330.8 & 317.9 & 286.5 \\
$\quad$ Employed part-time & & & & & & \\
$\quad$ Children <5 & 331.3 & 283.6 & 326.1 & 282.6 & 348.7 & 275.6 \\
$\quad$ Children >5 & 416.5 & 308.4 & 421.0 & 325.1 & 337.7 & 312.6 \\
$\quad$ No children & 450.1 & 371.2 & 461.0 & 379.2 & 398.2 & 354.5 \\
$\quad$ Not employed & & & & & & \\
$\quad$ Children <5 & 463.8 & 333.4 & 483.2 & 341.4 & 416.5 & 327.4 \\
$\quad$ Children >5 & 493.6 & 396.6 & 528.9 & 374.3 & 472.6 & 391.7 \\
$\quad$ No children & 545.4 & 468.6 & 534.7 & 465.7 & 522.4 & 449.2
\end{tabular}

Note: Data presented as fitted values of minutes of leisure time per day. All other analysis variables have been set to their medians or means.

and employment status, with no further variation explained by the higher order conditional relationship between all three variables.

The three-way conditional relationship between gender, employment status, and parental status found in Canada and the UK indicates that women who are employed full-time with children under the age of five experience the greatest disadvantage in available leisure time. This result suggests the importance of gender in explaining the differential effect of young children and full-time employment in the lives of men and women. While men who are employed full-time with young children have the lowest levels of leisure among other men, the effect of young children does not as thoroughly diminish their leisure as it does women's leisure time. It must be understood, however, that full-time employment is an important factor that leads to more similar leisure time among men and women with varying parental statuses. The effect of being employed part-time or not being in the labour force increases the overall average of leisure, but also, importantly, exacerbates the gender gap in leisure time. Part-time employment is an option frequently chosen by mothers with children to alleviate the double burden of full-time employment and parenthood (Michelson 1985). Interestingly, the fitted values of leisure time are lower in the US at every combination of gender, employment, and parental status with the exceptions of American fathers of young children under the age of five and American mothers who are not employed with children over the age of five.

Conditional Relationships with Time: Differentiation and Convergence in Leisure Time 
The preceding analyses show that leisure time has increased only marginally in Canada and, following a period of reversal, in the US while no significant increase in the UK is discernable. Change in the impact of specific social characteristics on leisure activity over time was tested in a series of two-way conditional effects with survey year. Four possible sources of variation in the effect of social characteristics by survey year will be investigated. Separate analyses for men and women are pursued due to the complexity of specifying conditional effects with year and two-way and higher order conditional relationships between gender, employment status, and parental status. The significance of F-tests for conditional effects with year is presented in Table 5 .

In each national context, there are significant conditional relationships between year and gender. Plotting fitted values (Figure 2) demonstrates a modest trend toward increasing similarity in patterns of male and female leisure time. In the US, the difference between men and women's leisure time decreased from 81-50 minutes, while in Canada the gender gap decreased from 93 minutes in 1971 to 59 minutes by 1998 . Convergence in men and women's leisure time was less pronounced in the UK, decreasing from 67-62 minutes. Clearly, over time, gender is an important variable leading to a more similar pattern of leisure between men and women, despite the persistence of a gendered gap in leisure time. While this gap may be partially explained by the greater amount of time that women spend in personal care activities relative to men (Robinson and Godbey 1997), it nonetheless suggests that gender roles are slow to change even under conditions of widespread female labour market participation.

For each country studied, there is a significant conditional effect between year and parental status over time indicating that available leisure time has become increasingly differentiated by the presence and age of children within the home. The parental gap in leisure time has become more pronounced, especially when children are under the age of five (Figure 3). The difference in leisure time available to the parents of children under the age of five and those parents of children above the age of five increased in the US from 23-40 minutes, in Canada from 43-46 minutes, while in the UK the difference between parents of younger and older children increased from 4-42 minutes. In each national context, the gap in leisure time between those with and without children also increased considerably. This difference in leisure time is one indication that the lives of parents and nonparents have become increasingly dissimilar. Separate analyses for male and female samples (Table 5) suggest that the conditional relationship between year and parental status is largely attributed to the impact of parenting on leisure experienced by women in the 


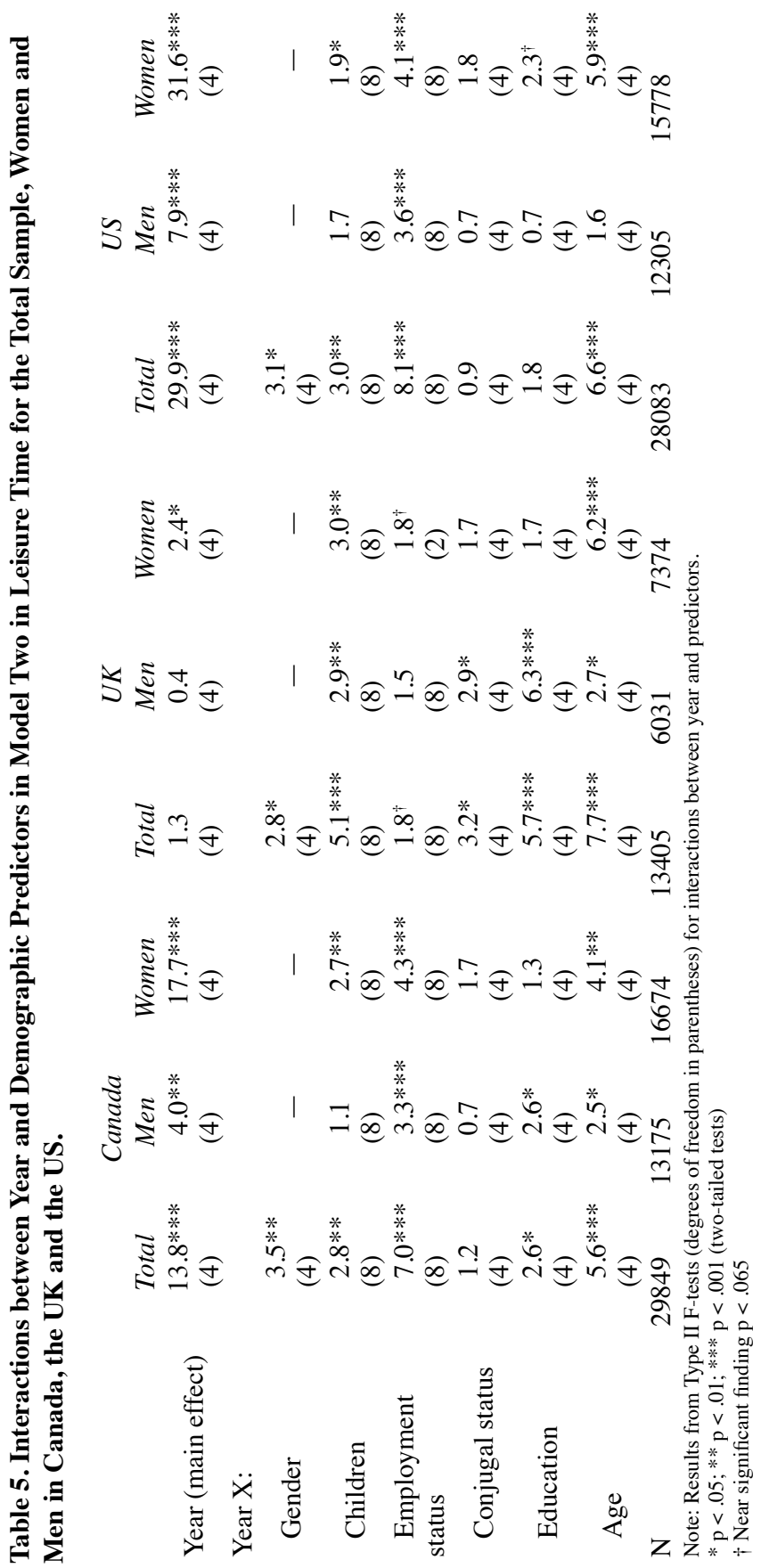


Figure 2. Fitted Number of Minutes of Leisure Activity for each Country by Gender Canada

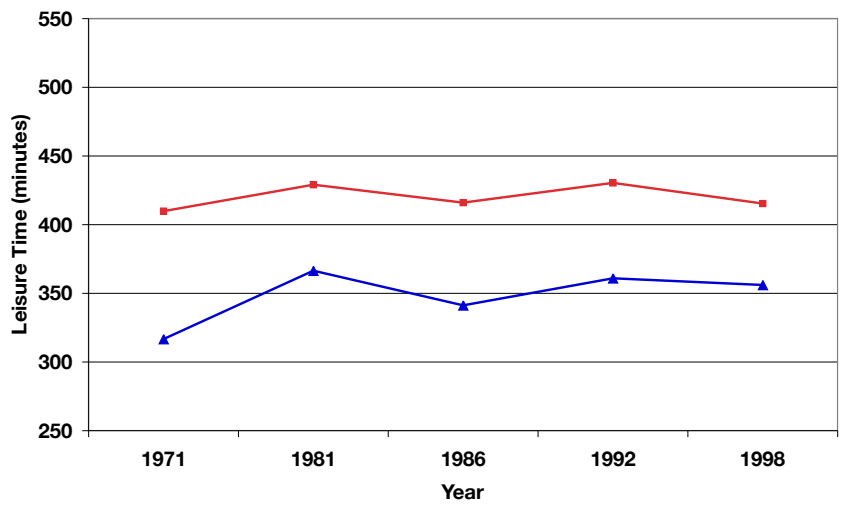

United Kingdom

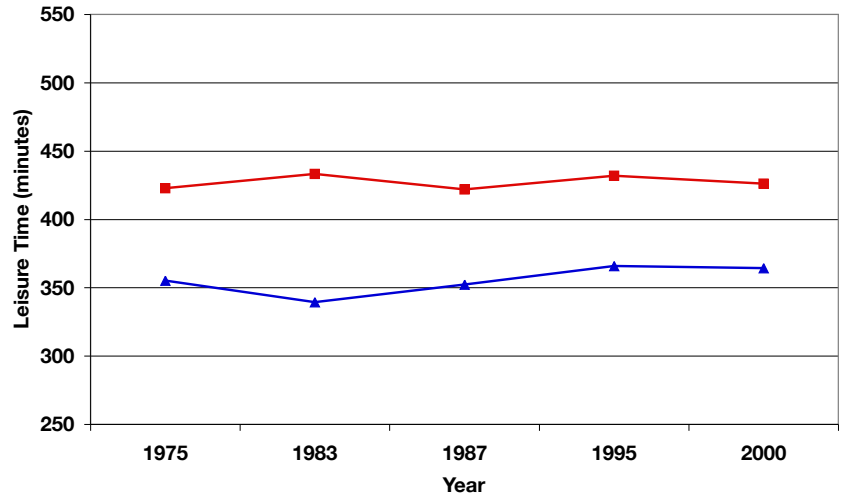

United States

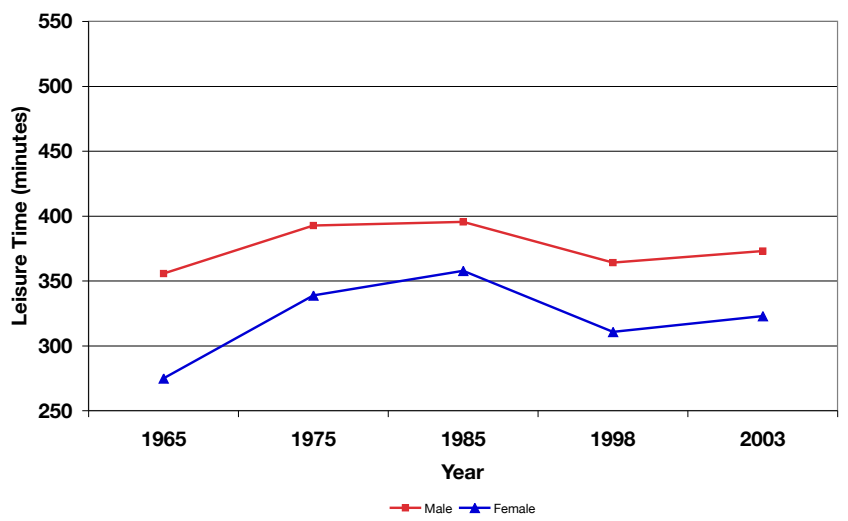


46 C Canadian Journal of Sociology/Cahiers Canadiens de sociologie 36(1) 2011

Figure 3. Fitted Number of Minutes of Leisure Activity for each Country by Parental Status

Canada
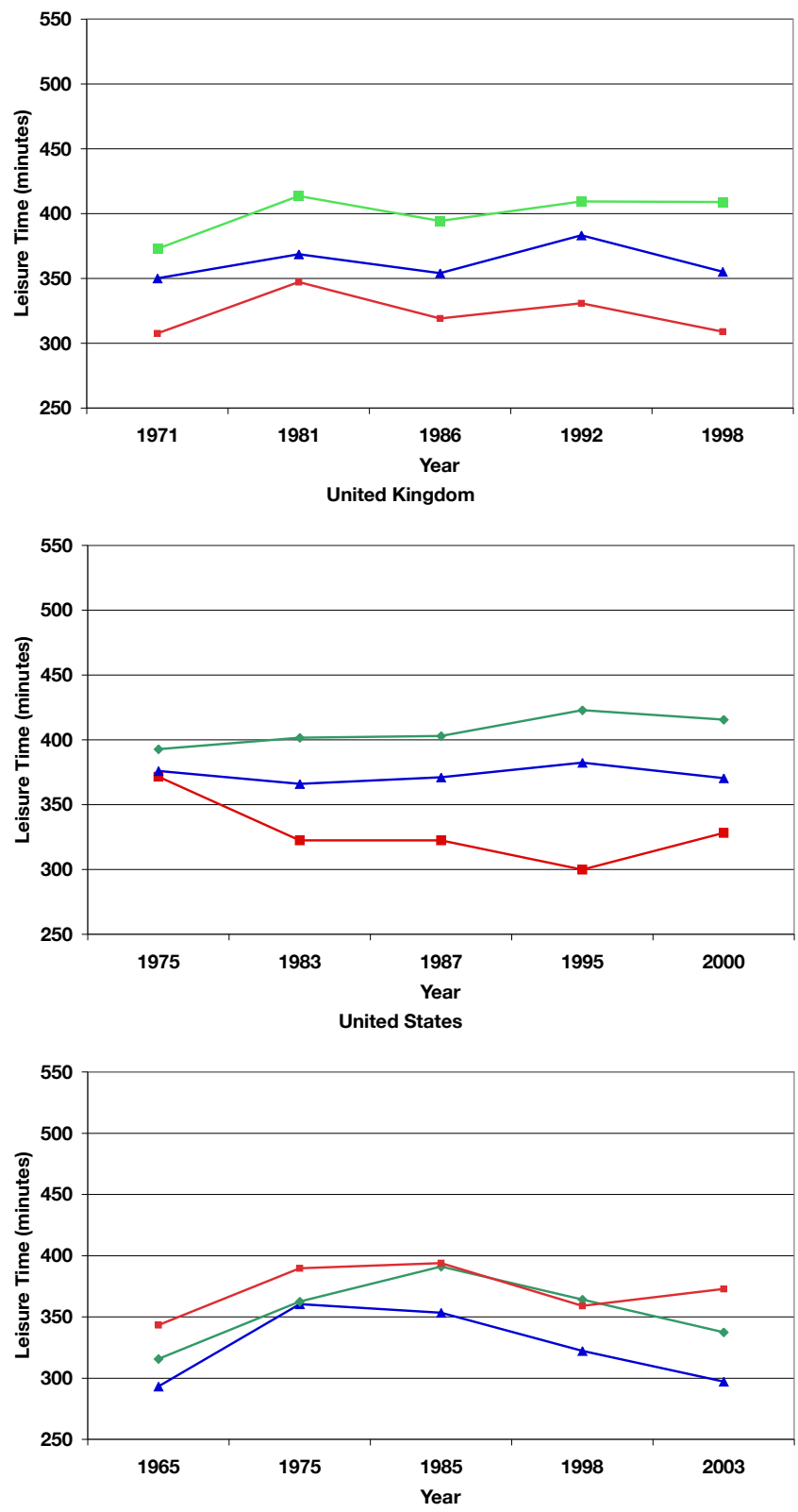

$\rightarrow$ Children $<5 \longrightarrow$ Children $>5 \rightarrow-$ No Children 
Figure 4. Fitted Number of Minutes of Leisure Activity for each Country by Employment Status

Canada
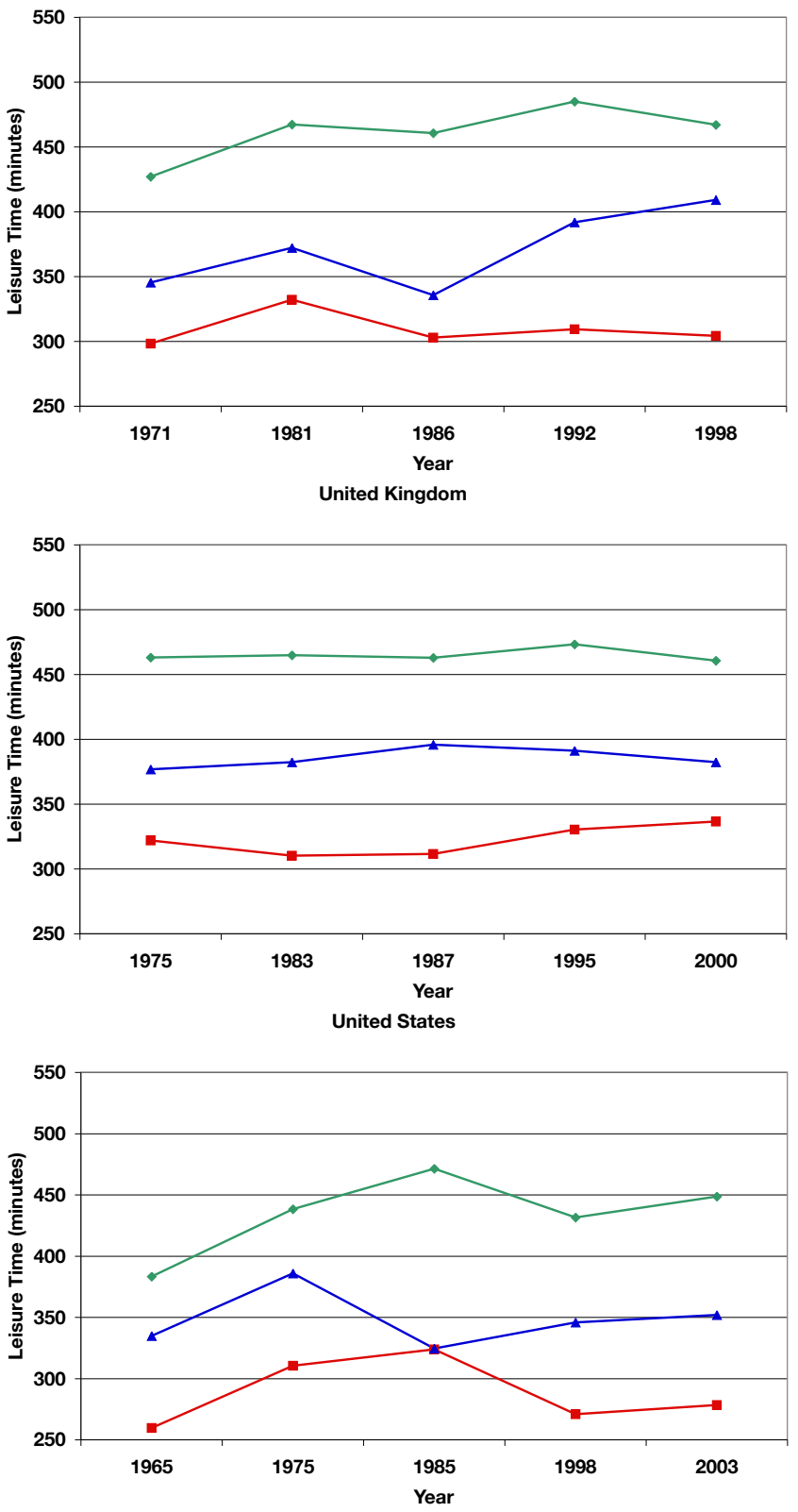
US and Canada. Significant conditional effects for both men and women in the UK indicate that the effect of parental status has led to increased differentiation in the leisure time available to men and women.

Evidence for a growing difference in leisure time by employment status is found in the US and Canada. The fitted values (Figure 4) clearly show that available leisure time has diverged increasingly based on one's involvement in the labour market. In the US, the difference in the amount of leisure available to those employed full-time and those not in the labour market increased from 124 in 1965 to 170 minutes by 2003 . Similarly, in Canada, the gap in leisure time between those employed full time and those not in the labour market increased from 130-163 minutes. Within Canada, there was also a pronounced growth in the disparity of leisure time among those employed full-time and part-time. Separate analyses for men and women demonstrate increased differentiation in leisure time by employment status for both genders. No similarly significant finding was found for the UK.

Conjugal status did not explain variation in leisure time in either Canada or the US, while a significant effect was only found among men in the UK. Consequently, there is little reason to believe that increasingly similar gender roles have affected the efficiency of household production, thereby further constraining available time for leisure. Variation in national trends demonstrate the impact of late modern change on patterns of activity that are both becoming more similar on the basis of gender and increasingly different on the basis of parental and employment status.

\section{Discussion ANd Conclusion}

Little support is found for the much berated thesis of the leisure society (Dumazedier 1967) that posits dramatic gains in leisure time among industrialized societies. Nor is there strong evidence to support the position that leisure time has dramatically decreased within the populations of Canada or the UK, though the US has experienced a recent decline in average leisure time. Overall, small net increases in Canadian and American leisure time have occurred, while leisure in the UK remained stable at a higher net level of leisure time. There is less leisure time in the US compared to Canada and the UK. Furthermore, full-time employment is a larger constraint on the leisure time of Americans and Canadians. This finding lends some support to the expectation that these economies are more market dependent and have labour markets that are subject to fewer controls on work time. 
Esping-Anderson's (1990) work on welfare state regimes would suggest that American leisure time is lower because of market oriented social policies, fewer universal entitlements, and labour protections that may increase workers' dependence on market work. Despite these differences in the national policy contexts, all nations included in analyses vary on a continuum of liberal welfare state provision. The United States is characterized as the most liberal welfare state in the provision of social welfare, lacking some of the universal social and health provisions found in Canada and the UK. The absence of additional labour and social supports may curtail leisure time due to increased dependence on market work. While the difference and direction of change in leisure time within these nations may be illustrative of their state welfare regime strategies, mean national leisure time is relatively stable at the level of the population and additional changes within the family, gender, and the organization of work have contributed to differences in leisure by parental status and increased similarity based on gender.

Gershuny argues that societal balance must be attained between the time allocated to production and consumption. Ursel (1992) has further argued that investments of time and resources in reproduction must be balanced, either through natural births or immigration, with the needs of production. Given these perspectives, there is less cause to look for dramatic changes in the amount of time that a nation invests in market work, domestic work, and leisure. The economic balancing act between production, consumption, and domestic work, or reproduction at the aggregate level suggests that we should expect a relatively stable amount of time available to leisure over time. Rather, there is cause to investigate how the distribution of time in productive activities and leisure has changed over time by social characteristics. National mean time in market work and leisure can mask substantial social changes and rebalancing of time by demographic and social characteristics of groups. These changes are introducing greater inequities in leisure among the parents of children and those who are childless. Complex social change also allows for greater gender equality in leisure time among men and women, while men, and especially women, of young children have markedly less leisure.

It has been claimed that increased working hours and domestic obligations demonstrate that leisure time has lost its marginal utility among individuals with high socioeconomic status (Gershuny 2000). Linder (1970) predicted that as individuals achieved greater economic gains, they would compensate for their loss of leisure time by increasing the marginal utility of their leisure and consuming the offerings of the burgeoning consumer society. Further research is needed to understand how 
individuals heavily invested in market labour are using their leisure. Additional research should address how parenting affects leisure during a stage in the life-course when both time and family economic resources are intensely focused on raising children and establishing a household. The consequence of limited leisure time for restoration from market work, domestic work, and care giving is an important area of emerging research. The direction of change in the distribution of leisure within societies is key to understanding the effect of time inequalities on health and wellbeing outcomes.

Increasingly constrained leisure time among parents of young children suggests that existing familial relationships are undergoing a period of reorganization that may be contributing to increased stress and decreased opportunities for leisure. Social policy has been outpaced by new work and family arrangements that are contributing to stressful, if not disorganized, family relations (Moen and Sweet 2003; Ruhm 2005; Waldfogel 2005). These strains are the result of costs in time being paid by parents of young children and the reluctance to alleviate the costs of parenting, or reproduction, through social and family policy. As noted by Gershuny (2000), relative balance between production, reproduction, and consumption in needed within a society. Findings presented suggest that the distribution of leisure time, while less gendered, is increasingly differentiated by social characteristics that represent stages in the lifecourse. Leisure time is increasingly unequal for those who parent and raise children; thereby contributing to high workloads among working parents whose time-use is highly specialized in reproduction and production activities.

Social differentiation is a process, not a theory, of social change. Knowledge of that process is necessary, but not sufficient, to theoretically understand the character of the social change it produces. Classical contributions linked the process of differentiated economic roles to new forms of social solidarity based on economic interdependence (Durkheim 1964). The expected outcome of more differentiated social roles is increased specialization and the consequence of that specialization is determined by the context within which the change occurs.

More contemporary accounts, such as the postmodernization perspective of Crook et al. (1992), suggest that differentiation, as a process, may disorganize social relations and allow greater inequality or equality to emerge between groups. For instance, while Gershuny (2000) has observed increased similarity, or convergence, in male and female domestic roles and leisure time, findings presented here demonstrate an increased difference based on parental status. These emerging role equalities and inequalities, largely the product of similar social change, nevertheless 
contribute to growing similarities among men and women and difference, that is differentiation, among parents and nonparents.

The factors responsible for differentiation in the amount of leisure time by parenting roles are potentially manifold. Women's increased labour force participation roughly coincided with postindustrialism, declining support for class-based politics and unionization, and retrenchment in the social policies of the welfare state beginning in the mid1970s (Korpi and Palme 2003). Higher female human capital, the result of higher levels of education, contributed to delayed marriage and childrearing (Cohen and Bianchi 1999; Schlesinger and Schlesinger 1989) and, presumably, an increased reluctance to forego the income that could be realized through market work. This is especially noteworthy given women's recent superior education attainment relative to men.

It can be assumed that social actors are realizing the market gains available within a context of family social policy that is reluctant to socialize the costs of reproduction (Folbre, 1994). Ursel's (1992) historical analysis of Canadian policy demonstrates a willingness to cede liberal rights to female employment and protections while on the job and a reluctance to offer more universal supports to offset the domestic care demands of women in the labour force. While actors will rationally test their marginal utility vis-à-vis the labour market, this calculation in the absence of a structural understanding of social change does not explain why parenting and nonparenting roles have become increasingly differentiated, especially among women.

This structure of constraint has contributed to increased differentiation in parenting roles by extending liberal rights to work, but stopping short of socializing reproduction. Under these circumstances, individuals may pursue more egalitarian arrangements with their partners or, alternatively, mothers may assume a double burden of market and domestic work. In either circumstance, parents will need to do more work than nonparents. Increased demand for female market work labour creates unmet need within the household and foregoing leisure time provides that need. As Moen and Sweet (2003) observe, this change in the gender division of market and domestic work has contributed to a "lag" in social policy, whereby family policies have not caught up to the reality of working parents' lives. Consequently, in late modernity, there are new opportunities, specifically with respect to the right of employment among women, and emerging inequalities in the amount of work based on one's set of social roles. Clearly, it can additionally be appreciated that there are fewer policy costs associated with the granting of liberal rights than universal social provision. 
Additional research is needed to investigate patterns of change in different national welfare regime contexts. Analyses demonstrated broadly similar patterns of change in leisure time among liberal welfare state regimes. Despite similarities, lower mean leisure time is observed in the US, confirming its position as a highly liberal and market oriented Western democracy. European countries have successfully pursued national social policies that provide families with greater resources to negotiate their work in the market and within the home. Provision of family allowance, pension contributions for care giving, and extended benefits for part-time employment will increase the marginal utility of parenting and care giving (Jacobs and Gerson 2004), while affordable and accessible day-care, generous paternal leave for both fathers and mothers, and regulating the hours of work reduce pressures on the management of work and family roles and responsibilities. These resources change the context in which families attempt to maximize their financial security and reduce the economic necessity of the male breadwinner. To this end, social policy affects a society's allocation of time.

The investments and costs of parenting have been ignored in social policies that have increasingly encouraged the full economic participation of women through the provision of liberal market protections, without providing families with the resources to manage the transition toward more egalitarian gender patterns of work and family life. Current policy configurations may impede greater gender equality and exacerbate the growing inequity in leisure time among families raising children and those who remain childless. Further comparative analysis of liberal and social democratic welfare regimes may contribute to our understanding of the impact of public policy on the structure of work and family life and its impact on the distribution of leisure within the society. 
Appendix 1. Technical Details of MTUS Surveys Included in Analyses.

Year Sample Size Response Rate (\%) Diary Day Type of Diary Day Canada

\begin{tabular}{lrrl}
1971 & 2141 & 72.0 & 1 on day \\
1981 & 2686 & 46.0 & 1 on day \\
1986 & 9946 & 78.9 & 1 on day \\
1992 & 9815 & 77.0 & 1 recall \\
1 recall \\
1998 & 10749 & 77.6 & \\
\multicolumn{2}{l}{ United Kingdom } & & \\
1961 & 2363 & 69.8 & 1 on day \\
$1974 / 5$ & 3583 & 60.0 & 1 on day \\
$1983 / 4$ & 1525 & 51.0 & 1 on day \\
1987 & 3035 & 70.0 & 1 on day \\
1995 & 1875 & 93.0 & 1 recall \\
2000 & 11667 & 45.0 & 1 on day \\
United States & & & 1 on day \\
1965 & 1243 & 74.0 & 1 on day \\
$1975 / 6$ & 2406 & 72.0 & 1 on day and recall \\
1985 & 5358 & 55.2 & 1 recall \\
$1992 / 4$ & 9386 & 63.0 & 1 recall \\
$1998 / 2001$ & 1700 & 56.0 & 1 recall \\
2003 & 20720 & 57.0 &
\end{tabular}

Note: Information for this table was derived from Fisher, Kimberly, with Jenifer Tucker, Antony Jahandar and other members of the Time Use Team (2006) Technical Details of Time Use Studies. Last updated 1 February 2006. Institute for Social and Economic Research, University of Essex (http://www.timeuse.org/mtus/) 
54 C Canadian Journal of Sociology/Cahiers canadiens de sociologie 36(1) 2011

Appendix 2. Type II F-tests for Overall Significance of Model Two Predictors.

$\begin{array}{cccc} & \text { Canada } & \text { UK } & \text { US } \\ \text { Year } & 13.7 * * * & 1.3 & 29.7 * * * \\ & (4) & (4) & \text { (4) }\end{array}$

Children 271.7***

$210.8 * * *$

$174.8 * * *$

(2)

(2)

(2)

Gender

$859.4 * * *$

$584.2 * * *$

$470.2 * * *$

(1)

(1)

(1)

Employment status

$1691.9^{* * *}$

$802.7 * * *$

$1355.5^{* * *}$

(2)

(2)

(2)

Conjugal status

243.6***

$169.8^{* * *}$

$124.7 * * *$

(1)

(1)

(1)

Education

0.4

$27.0 * * *$

0.002

(1)

(1)

(1)

Age

$61.5^{* * *}$

$17.9^{* * *}$

$148.8 * * *$

(1)

(1)

(1)

Age $^{2}$

$92.2 * * *$

$164 * * *$

$181.3^{* * *}$

(1)

(1)

(1)

Note: Results from Type II F-tests (degrees of freedom in parentheses) for interactions between survey year and predictors.

$* \mathrm{p}<0.05 ; * * \mathrm{p}<.01 ; * * * \mathrm{p}<.001$ (two-tailed tests) 


\section{REFERENCES}

Ås, Dagfinn. 1982. Designs for large scale, time-use studies of the 24-hour day. In Z. Staikov, ed., It is About Time: Proceedings of the International Research Group on Time Budgets and Social Activities. Institute of Sociology at the Bulgarian Academy of Sciences: Sofia, Bulgaria.

Becker, Gary S. 1981. A Treatise on the Family. Cambridge, MA: Harvard University Press.

Bianchi, Suzanne. 2003. Gender differences in the quantity and quality of free time: The U.S. experience." Social Forces 81(3):999-1030.

Bittman, Michael. 1998. The land of the lost long weekend? Trends in free-time among working age Australians, 1974-1992. Loisir and Société / Society and Leisure 21(2):353-378.

2000. The rush hour: The character of leisure time and gender equity. Social Forces 79(1):165-189.

Brewster, Karin L. and Irene Padavic. 2000. Change in gender ideology, 19771996: The contributions of intracohort change and population turnover. Journal of Marriage and the Family 62:477-87.

Brines, Julie. 1994. Economic dependency, gender, and the division of labour at home. American Journal of Sociology 100:652-88.

Cohen, Philip N. and Suzanne M. Bianchi. 1999. Marriage, children, and women's employment: What do we know? Monthly Labour Review 122(12):22-31.

Coverman, Shelley and Joseph F. Sheley. 1986. Change in men's housework and child-care time, 1965-1975. Journal of Marriage and the Family 48(2):413-22.

Crook, Stephen, J. Pakulski, and Malcolm Waters. 1992. Postmodernization: Change in Advanced Society. London: Sage Publications.

Cross, Gary. 1993. Time and Money: The Making of Consumer Culture. London: Routledge.

Dumazedier, Joffre. 1967. Toward a Society of Leisure. New York: The Free Press.

Durkheim, Emile. [1893] 1964. The Division of Labour in Society. New York: The Free Press.

Easterlin, Richard A. 1978. What will 1984 be like? Socioeconomic implication of recent twists in age structure. Demography 15:397-432.

Esping-Anderson, Gøsta. 1999. Social Foundations of Postindustrial Economies. Oxford: Oxford University Press. 1990. The Three Worlds of Welfare Capitalism. Princeton, NJ: Princeton University Press. 
Firestone, Juanita and Beth Anne Shelton. 1994. A comparison of women's and men's leisure-time: Subtle effects of the double day. Leisure Science 16(1):45-60.

Fisher, Kimberly, with Jenifer Tucker, Antony Jahandar and other members of the Time Use Team (2006) Technical Details of Time Use Studies. Last updated 1 February 2006. Institute for Social and Economic Research, University of Essex. http://www.timeuse.org/mtus/

Fox, John. 1987. Effect displays for generalized linear models. Sociological Methodology 17:347-61. 2007. I am grateful to Robert Andersen and David Firth and Michael Friendly for various suggestions. Effects: Effect Displays for Linear and Generalized Linear Models. R package version 1.0-10. http://www.rproject.org, http://socserv.socsci.mcmaster.ca/jfox/

Folbre, Nancy. 1994. Who Pays for the Kids? Gender and the Structures of Constraint. London: Routledge.

Garhammer, Manfred. 2002. Pace of life and enjoyment of life. Journal of Happiness Studies 3(3):217-256.

Gershuny, Jonathon. 2000. Changing Times: Work and Leisure in Postindustrial Society. Oxford: Oxford University Press. 2005 . Busyness as the badge of honour for the new superordinate working class. Social Research 72(2):287-314.

Gershuny, Jonathon and Oriel Sullivan. 2003. Time use, gender and public policy regimes. Social Politics 10(2):206-228.

Hochschild, Arlie Russel and Anne Machung. 1989. The Second Shift: Working Parents and the Revolution at Home. New York: Viking.

Jacobs, Jerry A. and Kathleen Gerson. 2004. The work-home crunch. Contexts 3(4):29-37.

Jacobs, Kathleen and Jerry A. Jacobs. 1998. Who are the overworked Americans? Review of Social Economy 56(4):442-59.

Korpi, Walter and Joakin Palme. 2003. New politics and class politics in the context of austerity and globalization: Welfare state regress in 18 countries, 1975-95. American Political Science Review 97(3):425-446.

Levy, Frank. 1995. Incomes and income inequality. In Reynolds Farley, ed., State of the Union: America in the 1990s. New York: Russell Sage Foundation.

Linder, Steffan. 1970. The Harried Leisure Class. New York: Columbia University Press.

Mårtensson, Solveig. 1979. On the formation of biographies in space-time environments. Lund Studies in Geography, Series B. Human Geography No. 47. Gleerup: The Royal University of Lund.

Michelson, William. 1985. From Sun to Sun: Daily Obligations and Community Structure in the Lives of Employed Women and their Families. Totowa, N.J.: Rowman and Allanheld. 
Moen, Phyllis and Stephen Sweet. 2003. Time clocks: Work hour strategies. In P. Moen, ed., It's about time: Couples and Careers. Ithaca, NY: Cornell University Press.

Multinational Time Use Study, Version 5.5.2 (released 14 October 2005). Created by Jonathan Gershuny, Kimberly Fisher and Anne H. Gauthier, with Alyssa Borkosky, Anita Bortnik, Donna Dosman, Cara Fedick, Tyler Frederick, Sally Jones, Tingting Lu, Fiona Lui, Leslie MacRae, Berenice Monna, Monica Pauls, Cori Pawlak, Nuno Torres and Charlemaigne Victorino. ISER, University of Essex, Colchester, U.K... http://www.timeuse. org/mtus/

Olsen, Gregg. 2002. The Politics of the Welfare State. Toronto: Oxford University Press.

Oppenheimer, Valerie Kincade. 1997. Women's employment and gains to marriage: The specialization and trading model. Annual Review of Sociology 23:431-53.

R Development Core Team. 2007. R: A Language and Environment for Statistical Computing. Vienna: R Foundation for Statistical Computing. http:// www.R-project.org.

Rapoport, Rhona and Robert N. Rapoport. 1975. Leisure and the Family Life Cycle. London: Routledge and Kegan Paul.

Robinson, John P. 1985. The validity and reliability of diaries versus alternatives time-use measures. In F.T. Juster and F.P. Stafford, eds., Time, Goods, and Well-Being. University of Michigan: Institute for Social Research.

Robinson, John P. and Geoffrey Godbey. 1997. Time for Life: The Surprising Ways Americans use their Time. University Park, PA: Pennsylvania State University Press.

Robinson, John. 1999. The time-diary method: Structures and uses. In W.E. Pentland, A. Harvey, and M.P. Lawton, eds., Time-use Research in the Social Sciences. New York: McColl, Kluwer Academic/Plenum Pub.

Robinson, John P. and Jonathan Gershuny. 1994. Measuring hours of paid work: Time-diary vs. estimate questions. Bulletin of Labour Statistics, xi-xvii. Geneva: International Labour Office.

Ruhm, Christopher J. 2005. How well do governments and employer policies support working parents? In Suzanne M. Bianchi, Lynne M. Casper, and Rosalind Berkowitz King, eds., Work, Family, Health, and Well-Being. Mahwah, NJ: Lawrence Erlbaum Associates, Publishers.

Sanderson, Stephen K. 1990. Social Evolutionism: A Critical History. Cambridge, MA: Blackwell Publishers.

Sayer, Liana C. 2005. Gender, time and inequality: Trends in women's and men's paid work, unpaid work and free time. Social Forces 84(1):285-303.

Schor, Juliet. 1992. The Overworked American: The Unexpected Decline of Leisure. New York: Basic Books. 
Schlesinger, Benjamin and Schlesinger, Rachel. 1989. Postponed parenthood: Trends and issues. Journal of Comparative Family Studies 20(3):355363.

Shelton, Beth A. 1992. Women, men, and time: Gender differences in paid work, housework and leisure. Westport, CT: Greenwood Press.

Spencer, Herbert. [1902] 1958. First Principles. New York: DeWitt Revolving Fund.

Stalker, Glenn. 2006. Gender convergence and life-course differentiation in the Canadian use of time. Loisir and Société/Society and Leisure 29(1):15990.

Sullivan, Oriel and Jonathan Gershuny. 2001. Cross-national changes in timeuse: Some sociological (hi)stories re-examined. British Journal of Sociology 52(2):331-347.

Szalai, Alexander, ed. 1972. The Use of Time. The Hague: Mouton.

Tilly, Charles. 1984. Big Structures, Large Processes, Huge Comparisons. New York: Russell Sage Foundation.

Thrane, Christer. 2000. Men, women, and leisure time: Scandinavian evidence of gender inequality. Leisure Sciences 22(2):109-22.

Ursel, Jane. 1992. Private Lives and Public Policy: 100 Years of State Intervention in the Family. Toronto: Women's Press.

Veblen, Thorstein. 1899. The Theory of the Leisure Class: An Economic Study in the Evolution of Institutions. New York: The Macmillan Company.

Vosko, Leah. 2003. Gender differentiation and the standard/non-standard employment distinction: A genealogy of policy interventions in Canada. In Danielle Juteau, ed., Social Differentiation: Patterns and Processes. Toronto: University of Toronto Press.

Waldfogel, Jane. 2005. Work and family research: A public policy perspective. In Suzanne M. Bianchi, Lynne M. Casper, and Rosalind Berkowitz King, eds., Work, Family, Health, and Well-Being. Mahwah, NJ: Lawrence Erlbaum Associates, Publishers.

White, Lynn and Stacy J. Rogers. 2000. Economic circumstances and family outcomes: A review of the 1990s. Journal of Marriage and the Family 62:1035-51.

Glenn Stalker is assistant professor in Sociology and Associate Director at the Institute for Social Research (ISR) at York University, Toronto, Ontario, Canada. His research interests are in work and leisure, environmental sociology, and cultural capital.

gstalker@yorku.ca 